1 Doyle PJ, Stevens HE. Esophageal diverticula. In: Cummings $\mathrm{CW}$, ed, Otolaryngology-head and neck surgery. S Luois: Mosby-Year Book Inc, 1993; pp 2369-81.

2 Ertekin C, Pehlivan M, Aydogou I, et al. An electrophysiological investigation of deglutition in man. Muscle Nerve 1995;18:1177-86.

3 Shockley WW. Esophageal disorders. In: Bailey BJ, ed, Head and neck surgery - otolaryngology. Philadelphia: JB Lippincott, 1993; pp 690-710.

4 Nilsson ME, Isberg A, Schiratzki $H$. The hypopharyngeal diverticulum. A simultaneous cineradiographic and manometric examination. Acta Otolaryngol Stockh 1988;106:314 20 .

5 Tsipouras P. Marfan syndrome: a mystery solved. $\mathcal{f}$ Med Genet 1992;29:73-4.
6 Judo KP. Hyperelasticity syndromes. Cutis 1984;33:494-6. 7 Kainulainen K, Pulkkinen L, Savolainen A, Kaitila I, Peltonen L. Location on chromosome 15 of the gene defect causing Marfan's syndrome. N Engl f Med 1990;323. 935-9.

8 Hollister DW, Godfrey M, Sakai LY, Pyreritz RE. Immunohistologic abnormalities of the microfibrillar-fiber system in histologic abnormalities of the microfibrillar-fiber system
the Marfan syndrome. N Engl $\mathcal{F}$ Med 1990;323:152-9.

9 Lee B, Godfrey M, Vitale E, et al. Linkage of Marfan's syndrome and a phenotypically related disorder to two differen fibrillin genes. Nature 1991;352:330-4.

10 Suster SM, Ronnen M, Bubis JJ. Diverticulosis coli in association with Marfan's syndrome. Arch Intern Med 1984; 144:203.

\title{
Recurrent infections and multiple bone fractures in a 4-year-old child
}

\author{
Ashok Vaghjimal, Jenny Shliozberg, Arye Rubinstein
}

A 4-year-old boy was referred to our clinic for evaluation of repeated skin infections, pneumonias, and recurrent otitis media starting from 9 months of age. The child had a history of eczema from one week of age. At the age of 3.5 years, he had sustained three fractures of long bones after a minor trauma. The family history was unremarkable. On physical examination he had an unusual and typical facies (figure), onychomycosis of finger nails and fading eczema on the right forearm. The rest of the physical examination was normal. The white cell count was elevated at $20.0 \times 10^{9} / 1$ with $20 \%$ eosinophils. Serum IgG, A and $M$ were normal. T and B cells were also within normal limits, both as percentages and in absolute numbers. Delayed-type hypersensitivity skin tests with Candida, tetanus toxoid and purified protein derivative were negative.

\section{Albert Einstein \\ College of Medicine, \\ Division of Allergy and \\ Immunology, Mazer \\ Building Room 200, \\ 1300 Morris Park \\ Avenue, Bronx, NY \\ 10461, USA \\ A Vaghjimal \\ J Shliozberg \\ A Rubinstein}

Accepted 10 March 1998

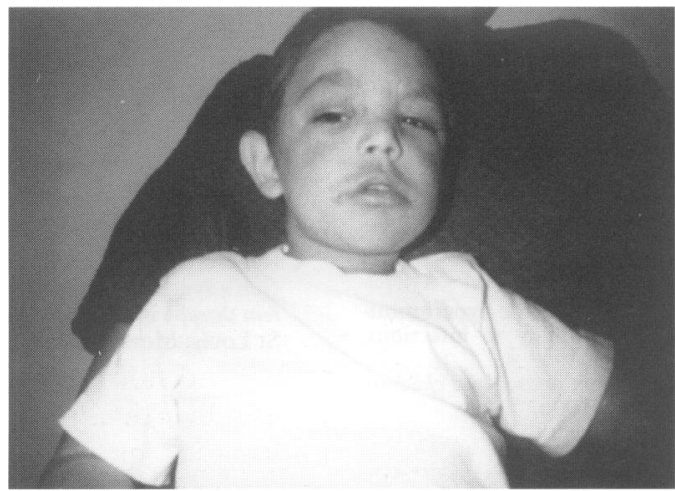

\section{Questions}

1 What tests should be performed?

2 What is the probable diagnosis? 


\section{Answers}

QUESTION 1

Serum IgE should be measured and a leucocyte chemotaxis test performed. Serum IgE was $23000 \mathrm{IU} / \mathrm{ml}$ in our patient (normal range 8-69 IU/ml). The leucocyte chemotaxis test was normal.

QUESTION 2

Hyper-IgE syndrome (Job's syndrome).

\section{Discussion}

Originally described in two red-haired girls with recurrent 'cold abscesses', Job's syndrome is a rare disorder characterised by elevated serum IgE levels, eczema and recurrent bacterial infections (box 1). ${ }^{1}$ The eczema is atypical and is present in nearly all patients. The affected skin is prone to bacterial and viral super-infections.

Recurrent pneumonias are the most serious infections in Job's syndrome, often resulting in pneumatocoele formation and empyema. Oral thrush, gingivitis and onychomycosis are described less frequently. ${ }^{2}$ Coarse facial features with a broad nasal bridge are present in the majority of the patients. Osteoporosis has also been reported in some patients and may be associated with an increased incidence of bone fractures.

A number of immunological abnormalities have been described in Job's syndrome; ${ }^{3}$, the main ones are summarised in box 2 . The white cell count may also be elevated, as was the case in our patient.

No specific therapy exists for this syndrome. Early recognition of infections and prompt treatment is necessary to prevent various complications. Dicloxacillin and trimethoprim-

1 Davis SD, Schaller J, Wedgwood RJ. Recurrent cold abscesses. Lancet 1966;1:1013-4.

2 Buckley RH, Wray BB, Belmaker EZ. Extreme hyperimmunoglobulinemia E and undue susceptibility to infections. noglobulinemia $\mathrm{E}$ and und

3 Stiehm ER, ed. Immunologic disorders in infants and children, 4th edn. Philadelphia: WB Saunders, 1996.

\section{Job's syndrome: clinical features}

atopic dermatitis

recurrent skin infections

- recurrent sinopulmonary infections

- coarse facial features

\section{Box 1}

\section{Job's syndrome: major immunologic} features

- markedly elevated serum IgE ( $>2000 \mathrm{IU} / \mathrm{ml}$ )

- eosinophilia of blood and sputum

- normal T and B cell numbers

- defective neutrophil chemotaxis (variable)

anergy in delayed hypersensitivity testing

- impaired antibody response to protein and polysaccharide antigens

Box 2

sulphamethoxazole have been used successfully to prevent infections. Topical steroids, emollients and antihistamines should be used to treat atopic dermatitis. Pneumococcal, influenza and varicella vaccines are also recommended, although multiple boosts may be necessary with the pneumococcal vaccine to obtain adequate antibody titres. Experimental therapies of Job's syndrome include plasmapheresis and intravenous immunoglobulin. ${ }^{4}$

\section{Final diagnosis}

Hyper-IgE syndrome (Job's syndrome).

Keywords: hyperimmunoglobin E; Job's syndrome

4 Roberts RL, Stiehm ER. Hyperimmunoglobin E syndrome (Job's syndrome). In: Lichtenstein LM, Fauci AS, eds, Current therapy in allergy, immunology, and rheumatology, 5 th edn. St Louis: Mosby, 1996. 